Linguista: Jurnal IImiah Bahasa, Sastra, dan Pembelajarannya

Vol.3, No.2, Desember 2019, hal 133-144

ISSN (print): 2579-8944; ISSN (online): 2579-9037

Avaliable online at: http://e-journal.unipma.ac.id/index.php/linguista

\title{
Ideologi Pesantren Sebagai Agent of Change pada Novel Negeri 5 Menara Karya Ahmad Fuadi (Sebuah Analisis Wacana Kritis)
}

\author{
Dwi Andriani \\ MTsN Ngunut, JI. Raya Magetan, Ngunut 3, Kabupaten Ponorogo, Indonesia \\ e-mail: andriani_dwi@gmail.com
}

\begin{abstract}
Abstrak
Penelitian ini bertujuan untuk mendeskripsikan dan menjelaskan (1) ideologi pesantren dengan menggunakan analisis teks mikro (textual analysis) wacana kritis model Fairclough dalam novel Negeri 5 Menara karya Ahmad Fuadi, (2) ideologi pesantren dengan menggunakan analisis teks meso (discourse practice analysis) wacana kritis model Fairclough dalam novel Negeri 5 Menara karya Ahmad Fuadi, (3) ideologi pesantren dengan menggunakan analisis teks makro (socioculture analysis) wacana kritis model Fairclough dalam novel Negeri 5 Menara karya Ahmad Fuadi. Penelitian ini menggunakan metode deskriptif analitik dengan objek penelitiannya adalah ideologi pesantren dalam novel Negeri 5 Menara karya Ahmad Fuadi. Teknik pengumpulan data dalam penelitian ini adalah dokumentasi. Teknik yang digunakan untuk menganalisis data dalam penelitian ini adalah model alir (flow model) Miles dan Huberman. Sumber data yang digunakan berasal dari teks novel Negeri 5 Menara karya Ahmad Fuadi setebal 423 halaman. Hasil penelitian menunjukkan bahwa (1) terdapat ideologi-ideologi yang diterapkan di pesantren. Penggunaan kata-kata Islami menunjukkan bahwa di dalam Pesantren diajarkan perilaku-perilaku keislaman;(2) menggambarkan dan mengenalkan pola pendidikan pesantren yang sebelumnya tidak banyak diketahui banyak orang; (3) kisah nyata penulisnya yang menceritakan berbagai usaha dan rintangan dalam mewujudkan impian dan cita-cita.
\end{abstract}

Kata kunci: Analisis Wacana Kritis; Ideologi; Pesantren; Novel; Agent of Change.

\section{I/Islamic Boarding School Ideology as Agent of Change in the Novel ‘Negeri 5 Menara' Written by Ahmad Fuadi (A Critical Discourse Analysis)}

\begin{abstract}
The purposes of this research are to describe and explain: (1) Islamic boarding school ideology by using Micro text analysis (textual analysis), Fairclough critical analysis model in Ahmad Fuadi's Negeri 5 Menara. (2) Islamic boarding school ideology by using Meso text analysis (Discourse practice analysis, Fairclough critical discourse analysis model in the novel Negeri 5 Menara. (3) Islamic boarding school ideology by using Macro text analysis (Sociocultural analysis) in the novel Negeri 5 Menara. This research used analytical descriptive method with Islamic boarding school ideology in the novel Negeri 5 Menara as the research object. Documentation technique of data collection was used in this research. Technique of analyzing data used was flow model by Miles and Huberman. Data source were derived from 423 pages novel texts of Ahmad Fuadi's Negeri 5 Menara. The results show that: (1) There have been ideologies applied in Islamic boarding school. Islamic terms usage in the novel shows that in some islamic behaviors are also taught in the boarding school, (2) the analysis shows that there has been description and introduction to patterns of Islamic boarding school which hasn't
\end{abstract}


previously been recognized by many people. (3) The real story of the author who tells all sorts of efforts and obstacles in accomplishing his dreams.

Keywords: Crtitical Discourse Analysis; Islamic Boarging School; Ideology; Novel; Agent of change

\section{Pendahuluan}

Bahasa merupakan media bagi manusia dalam berkomunikasi. Melalui bahasa, manusia dapat mengungkapkan ide, pikiran, dan perasaannya. Saat ini, definisi bahasa telah berkembang sesuai fungsinya bukan hanya se $\neg$ bagai alat komunikasi, melainkan juga sebagai media perantara dalam pelaksanaan kuasa melalui ideologi. Salah satu media perantara dalam menyebarkan ideologi adalah dengan melalui sebuah karya sastra. Novel merupakan salah satu bentuk karya sastra. Sesuai pendapat Budianta (2008:19) yang menyatakan bahwa cerita yang terdapat dalam sebuah novel dapat difungsikan sebagai media pendidikan. Hal ini disebabkan novel merupakan salah satu bentuk perwujudan yang bersifat teknis dari metode cerita.

Kemunculan karya sastra, khususnya novel, memberikan peranan penting bagi pendidikan di Indonesia. Novel mampu memberikan sumbangsih penting bagi pendidikan apalagi novel bertema religi yang di dalamnya terdapat pesan-pesan epik mampu memberikan nilai-nilai pendidikan bagi pembacanya. Untuk memahami sebuah novel, pembaca harus mampu mengkaji penggunaan bahasa yang ada di dalamnya. Untuk itulah, dibutuhkan sebuah ilmu untuk mengkaji lebih dalam bagaimana dan apa maksud pengarang menciptakan novel tersebut.

Salah satu pendekatan yang digunakan untuk mengkaji penggunaan bahasa di dalam sebuah wacana (dalam hal ini novel) adalah dengan menggunakan Analisis Wacana Kritis (AWK). Hal ini sesuai dengan pendapat Darma (2009:49) yang menyatakan bahwa analisis wacana kritis adalah sebuah upaya untuk proses (penguraian) untuk memberi pen $\neg$ jelasan dari sebuah teks (realitas sosial) dari seseorang atau kelompok dominan yang kecende $\neg$ rungannya memiliki tujuan tertentu untuk men $\neg$ capai tujuan yang diinginkan. Ditegaskan pula Littlejhon (dalam Sobur, 2004: 49) bahwa analisis wacana tidak memperlakukan penyusun sebagai suatu tujuan sendiri, namun bertujuan menemukan fungsi dan makna.

Dalam teori analisis wacana kritis, analisis wacana tidak hanya dipandang sebagai sebuah studi bahasa, tetapi juga merupakan sebuah upaya untuk mengungkapkan maksud tersembunyi dari subjek yang mengemukakan suatu pernyataan. Dalam penerapannya, analisis wacana kritis memang menggunakan bahasa dalam suatu teks untuk dianalisis, tetapi analisis bahasa dalam hal ini bukan hanya melihat bahasa dari aspek-aspek kebahasaan, melainkan juga mengaitkan bahasa dengan konteks.

Penyingkapan ideologi di balik teks itulah yang menjadi tugas utama dalam analisis wacana kritis. Untuk melihat bagaimana pemakai bahasa membawa nilai ideologis tertentu, dibutuhkan analisis yang menyeluruh. Oleh karena itu, analisis harus dipusatkan pada bagaimana bahasa itu terbentuk dan dibentuk dari relasi sosial dan konteks sosial tertentu. Fairclough (dalam Darma, 2009:55) menjelaskan bahwa analisis wacana dapat dilihat dari segi teks, Teks dianalisis secara linguistik dengan melihat 
kosakata, semantik atau makna dan tata kalimat yang disajikan dalam novel ataupun berita. Titik perhatian dari Fairclough adalah melihat bahasa sebagai praktik kekuasan.

Dalam model Fairclough, analisis wacana dibagi dalam tiga dimensi, yaitu teks (text), praktik wacana (discourse practice), dan praktik sosiokultural (sociocultural practice).

Novel Negeri 5 Menara karya Ahmad Fuadi ini berbeda dengan novel Islam lainnnya. Jika pada novel Islami lainnya banyak yang mengangkat dari segi cerita percintaan, novel ini justru mengangkat cerita persahabatan yang berawal di sebuah pesantren. Novel ini juga menjadi salah satu novel best seller nasional dan telah difilmkan karena adanya kata hikmah yang ditampilkan dalam novel tersebut. Ahmad Fuadi berhasil menceritakan kehidupan pesantren dengan sangat menarik. Melalui persahabatan lima orang tokohnya, pembaca seolah-olah sedang menjadi salah satu dari lima tokoh yang diciptakan Fuadi tersebut.

Selain bercerita tentang persahabatan di dalam pesantren, novel Negeri 5 Menara karya Ahmad Fuadi ini berisi banyak kalimat pembangkit semangat dari para kiai dan ustaz. Kalimat-kalimat itulah yang akhirnya menjadi ikon dari novel ini. Salah satu kalimat yang menjadi mantra para tokohnya adalah Man jadda wajada yang artinya siapa yang bersungguh-sungguh pasti berhasil.

\section{Metode Penelitian}

Jenis penelitian yang akan digunakan peneliti adalah kualitatif deskriptif analitik. Metode kualitatif deskriptif ini digunakan untuk menguraikan dan menganalisis ideologi pesantren yang nampak pada novel Negeri 5 Menara karya Ahmad Fuadi dengan menggunakan analisis wacana kritis model Fairclough. Alasan peneliti menggunakan metode ini karena peneliti ingin memerikan dan mendeskripsikan ideologi pesantren yang nampak pada novel Negeri 5 Menara karya Ahmad Fuadi dengan menggunakan analisis wacana kritis model Fairclough. Analisis wacana kritis model Fairclough terhadap novel Negeri 5 Menara karya Ahmad Fuadi terbagi menjadi tiga dimensi yaitu dimensi tekstual (mikrostruktural), dimensi kewacanan (mesostruktural), dan dimensi praktis sosial budaya (makrostruktural).

Pada dimensi mikrostruktural, penelitian ini menggunakan teori Appraisal. Teori appraisal adalah suatu pendekatan yang mengeksplor, memaparkan, dan menjelaskan bagaiamana bahasa dipakai untuk menilai, mengambil jarak, mengonstruksi seseorang secara tekstual, dan menata posisi dan hubungan interspersonal. Dengan demikian, Appraisal akan berkenaan dengan bagaimana penutur atau penulis menilai orang secara umum, penulis/penutur lain dan tuturannya, benda-benda, peristiwa-peristiwa, dan lainlain sehingga terbangun kelompok yang sepaham dan kelompok yang berseberangan. Appraisal juga bisa dipakai untuk menantang mereka-mereka yang berbeda pandangan. Dalam hal ini, bahasa yang dipakai dan berbagai kosakata dipakai bertujuan menunjukkan ideologi pesantren yang digambarkan Ahmad Fuadi dalam novel Negeri 5 Menara. Teori appraisal membagi teks menjadi tiga bagian yaitu affect, judgement, dan appreciation. Affect adalah tentang penilaian atau ungkapan perasaan. Judgement adalah tentang penilaian terhadap seseorang. Appreciation adalah penilaian terhadap sesuatu, benda, atau hal selain manusia. 
Teknik pengumpulan data dalam penelitian ini adalah teknik pustaka. Teknik yang menggunakan sumber-sumber tertulis untuk memperoleh data. Pada novel Negeri 5 Menara, pembaca diposisikan pada tokoh Alif sehingga pembaca diharapkan dapat merasakan pengalaman dan perjuangan Alif dalam menempuh pendidikannya di Pondok Madani. Teknik analisis data yang digunakan dalam penelitian ini adalah teknik deskriptif. Analisis kewacanan memusatkan perhatian pada bagaimana produksi dan konsumsi teks. Dalam penelitian ini, produksi teks berasal dari penulis Negeri 5 Menara yaitu Ahmad Fuadi. Konsumsi teks dilihat dari resensi novel yang ada di media dan tanggapan pembaca.

\section{Hasil dan Pembahasan}

\section{A. Dimensi Tekstual (Mikrostruktural)}

Penulis mengawali cerita pada novel Negeri 5 Menara dengan mengenalkan tokoh-tokoh yang terlibat dalam novel. Tokoh yang muncul di awal adalah tokoh Alif, Amak, Ayah, dan juga tokoh lain yang mendukung perkenalan awal. Selain itu, penulis menyampaikan pandangan awal tentang sekolah agama secara umum yang selama ini banyak berkembang di masyarakat. Di bagian ini penulis belum begitu banyak membuka wacana tentang pendidikan pesantren. Penulis lebih banyak menyoroti tentang perbedaan sekolah umum dan sekolah agama dalam pandangan masyarakat yang direpresentasikan melalui tokoh Alif. Alif menganggap dengan sekolah di pesantren maka tidak akan dapat meraih cita-cita. Berdasarkan hasil penelitian, penggambaran tokoh Alif di awal cerita merupakan tokoh yang penuh keragu-raguan, ketidakpercayaan, serta keputusasaan karena cita-citanya yang selama ini dibangun runtuh seketika hanya karena perbedaan pandangannya dan pandangan orang tuanya mengenai pendidikan. Hal ini disebabkan orang tua Alif tidak setuju jika Alif mendaftar SMA selepas dari pendidikan tsanawiyah. Orang tua Alif lebih mengingingkan Alif untuk melanjutkan pendidikannya di Aliyah. Namun, pada bagian selanjutnya dijelaskan bahwa Alif lebih memilih melanjutkan pendidikannya di sebuah pondok di Jawa meski dengan setengah hati.

Pada bagian selanjutnya, diceritakan bahwa kehidupan Alif di Pondok Madani tak seperti yang ditakutkan Alif saat itu, meskipun terkadang keragu-raguan itu muncul. Penulis menceritakan bahwa dipondok pesantren ini tidak hanya dipelajari di ruangan kelas, tetapi menjadi oksigen, menjadi bagian dari kehidupan sehari-hari. Penulis menampilkan wacana baru dalam sistem pendidikan agama dan umum yang selama ini tidak banyak disinggung di media. Sebuah keterpaduan pendidikan umum dan pendidikan agama dalam sebuah lembaga pendidikan agama dengan metode modern.

Hal yang sangat penting dalam sistem pendidikan di pesantren adalah aturan dan kedisplinan. Wacana baru dalam sistem pendidikan pesantren yang selama ini jarang diungkap di media, yaitu setiap santri diwajibkan untuk menguasai bahasa asing dalam tempo empat bulan saja juga diceritakan oleh penulis.Setelah empat bulan, maka bahasa Inggris dan Arab menjadi bahasa percakapan sehari-hari para santri. Tidak diperbolehkan menggunakan bahasa asing atau bahasa daerah. Bahkan, penulis dengan bahasa hiperbola menambahkan, bermimpi pun harus dalam bahasa asing. 
Selain itu, sebelum memulai pelajaran pertama mereka di kelas, setiap santri diberi kata-kata motivasi oleh ustad yang menjadi wali kelas mereka. Penulis menerangkan bahwa kata-kata motivasi tersebut akan menjadi kompas dalam kehidupan para santri meskipun mereka telah lulus dari PM. Kata-kata itu adalah Man Jadda Wajada yang berarti Siapa yang bersungguh-sungguh akan mendapatkan hasilnya. Penggunaan istilah-istilah keislaman ini juga digunakan pada pidato-pidato politik di Indonesia yang merupakan hasil penelitian Ikawati dan Hartanto (2014) tentang Pidato Politik di Indonesia, yang menyatakan bahwa ketika membuka pidato, para orator mengawali dengan salam, baik dengan salam yang merujuk pada istilah atau kata-kata yang dipakai dalam Agama Islam Assalamu'alaikum, salam dalam agama Hindu Om Swastiastu, atau dalam Nasrani Shaloom.

Ada yang mengawali dengan semua salam dari berbagai agama karena kemungkinan besar pembicara atau yang menyampaikan pidato sudah paham benar bahwa pendengarnya atau hadirin yang ada datang dari berbagai golongan yang berbeda agamanya namun menyatu dalam komunitas yang sama. Mengingat tidak hanya satu agama yang ada di Indonesia, maka menjadi hal yang lumrah dengan membuka pidato dan memberi salam dengan berbagai cara dan istilah-istilah keagamaan yang ada. Pidato tersebut tidak hanya ditujukan kepada pendengar dari salah satu penganut agama saja, namun untuk semua. Namun, untuk kata-kata atau istilah keagamaan yang sering dipakai adalah dari istilah keagamaan dari Agama Islam, misalnya Bismillaahirrohmaanirohiim, Insyaallah, Allah SWT, dan Alhamdulillah. Tentu hal ini hanya merupakan ungkapan dari sebuah statemen yang disampaikan oleh orang yang beragama Islam. Bisa jadi karena Susilo Bambang Yudhoyono, Megawati Sukarnoputri dan Aburizal Bakrie beragama Islam, maka istilah-istilah umum dalam agama Islam untuk mengungkapkan sesuatu atau untuk menyebut dan merujuk sesuatu juga menggunakan istilah agama Islam yang mengacu pada Bahasa Arab. Persamaan dengan penelitian ini terletak pada penggunaan istilah-istilah agama Islam. Penggunaan istilah-istilah agama Islam menunjukkan bahwa Novel Negeri 5 Menara benar-benar ingin menceritakan kehidupan yang ada di Pondok Madani.

Aspek judgements bermuatan positif banyak ditemukan pada novel Negeri 5 Menara. Salah satunya tergambar pada cuplikan "Rumus man jadda wajadda terbukti mujarab. Kesungguhanku segera dibalas kontan. Dalam tempo hanya satu jam saja, secara ajaib kartuku terisi”. Penggunaan frasa dibalas kontan bermuatan positif. Hal ini sesuai dengan hasil penelitian Winarni (2012) tentang analisis appraisal system kumpulan wacana "sungguh-sungguh terjadi" pada surat kabar kedaulatan rakyat yang menyatakan bahwa pada data 13 menunjukkan bentuk judgement positif, yang ditunjukkan dengan kata "selesai bertugas sesuai SOP" dan "serius tapi santai". Pada kata"selesai bertugas sesuai SOP" dikatakan perilaku positif karena pengawas didalam data tersebut melakukan pekerjaan sesuai tanggung jawabnya sebagai seorang pengawas. Selanjutnya, pada kata "serius tapi santai" menunjukkan hal positif karena dalam data tersebut seorang pengawas berusaha menenangkan muridmurid yang diawasinya supaya tidak terlalu tegang dalam mengerjakansoal-soal ujian, selain itu cara menyampaikan pengawas tersebut kurang tegas.Persamaan dengan penelitian tersebut adalah sama-sama menunjukkan judgement positif. 


\section{B. Dimensi Kewacanan (Mesostruktural)}

Dalam kerangka Fairclough teks dibentuk dalam sebuah praktikdiskursus yang terdiri dari produksi dan konsumsi teks. Kedua hal tersebut, berhubungan dengan jaringan yang kompleks yang melibatkan berbagai aspek praktik diskursif. Dari berbagai faktor yang kompleks tersebut, setidaknya ada tiga aspek yang penting. Pertama, dari sisi individu penulis itu sendiri. Kedua, dari sisi bagaimana hubungan antara penulis dengan struktur organisasi media. Ketiga, praktik kerja/rutinitas kerja dari produksi teks mulai dari pencarian berita/sumber, penulisan,editing sampai muncul tulisan tersebut di media.

Ahmad Fuadi, penulis Negeri 5 Menara, merupakan alumni KMI Pondok Modern Darussalam Gontor Ponorogo Jawa Timur.Cerita Negeri 5 Menara merupakan kenangannya selama mengenyam pendidikan di pesantren tersebut. Seperti tokoh dalam novel Alif, Fuadi awalnya dipaksa untuk sekolah di sekolah agama oleh orangtuanya.Namun, setelah menjalani proses pendidikan di Gontor dan lulus, kemudian menyadari bahwa dirinya sangat beruntung dapat sekolah dilembaga pendidikan agama seperti Gontor.

Gontor telah memberinyainspirasi dan bekal untuk mengarungi hidup Fuadi lalu berpendapatbahwa jika pengalaman yang ia dapatkan selama di Gontor hanya dirinyasaja yang tahu, hal tersebut hanya akan bermanfaat untuk dirinyasendiri. Tetapi jika dituliskan dan disebarkan ke orang lain, hal tersebut tentu dapat bermanfaat bagi orang banyak dan memberikan inspirasi, meskipun tidak merasakan pendidikan Gontor secara langsung. Negeri 5 Menara merupakan novel pertama Fuadi. Namun, karyatulisnya dalam bentuk artikel telah tersebar di berbagai media massa.Sebelum menjadi penulis novel, Fuadi merupakan wartawan TEMPO dan VOA, yang sudah tentu memiliki kemampuan menulis dalam bentuk reportase. Sepintas cerita dalam Negeri 5 Menara tak ubahnya laporan jurnalistik yang dikemas dengan bahasa sederhana yang mudah dimengerti, kejadian dituliskan dengan berdasarkan urutan waktu, danpada bagian-bagian cerita tertentu, penulis menampilkan dirinya sendirisecara mandiri tanpa representasi melalui tokoh cerita.Selama proses penulisan Negeri 5 Menara, Fuadi tidak sendiri, teman, alumni dan ustaz di Gontor turut menyumbangkan ide.

Hal ini untuk mendukung cerita yang dialami Fuadi ketika masih berada di Gontor bersama dengan teman-temannya.Terbitnya Negeri 5 Menara hampir bersamaan dengan peristiwa pengeboman Hotel JW. Marriot di Jakarta pada Juli 2009 silam. Peristiwa tersebut kemudian mengait-kaitkan tersangkanya dengan pesantren. Sebelumnya, sejak peristiwa Bom Bali 1 dan 2, banyak pemberitaan yang mengaitkan pelaku terorisme dengan pendidikan pesantren. Namun, hal ini tidak memengaruhi Fuadi menyelami proses kreatif penulisan Negeri 5 Menara. Negeri 5 Menara sendiri bukanlah jawaban atas peristiwa terorisme di Indonesia yang sering mengaitkan pelakunya yang juga alumni pondok pesantren. Hal ini dikarenakan ide Negeri 5 Menara sendiri sudah muncul ketika Fuadi masih mengenyam pendidikan di Gontor. Awalnya bukan dalam bentuk novel tetapi buku tentang pesantren Gontor. Namun, proses pengerjaannya tertunda karena kesibukan penulis. Sekitar tahun 1999-2000, ide lama tersebut kemudian muncul lagi. Ketika penulis sekolah S2 di Amerika, ia berjumpa dengan kakak kelasnya di Gontor. 
Selama penulis keliling ke berbagai negara di Eropa dan Amerika, ia banyakmenjumpai alumni Gontor yang juga melanjutkan sekolah atau bekerja di luar negeri. Hal ini semakin menguatkan A. Fuadi untuk membuat tulisan tentang pendidikan di Gontor. Banyak alumni Gontor yang telah berhasil namun tidak banyak yang tahu mengenai metode pendidikan di Gontor atau pesantren secara umum. Dan akhirnya pada tahun 2008, Fuadi fokus untuk menyelesaikan novelnya. Tak lama setelah novel tersebut terbit kemudian terjadilah peristiwa pengeboman Hotel JW. Marriot. Jadi, dipihak penulis sendiri tidak ada hubungan antara Negeri 5 Menara yang bercerita tentang pendidikan pesantren dengan peristiwa terorisme di Indonesia. Menurut Fuadi sendiri novel ini merupakan harapannya terhadap dunia pendidikan di Indonesia. Selama ini apa yang terjadi dibalik pagar pesantren tidak banyak orang yang tahu. Dengan munculnya novel ini, masyarakat diharapkan memiliki pengetahuan dan wawasan baru tentang pendidikan terkhusus lagi pendidikan agama/pesantren. Menurut Fuadi kekurangan pendidikan di Indonesia adalah kurangnya pendidikan karakter terhadap peserta didiknya. Pendidikan karakter sendiri banyak ditampilkan Fuadi dalam novelnya. Konsep keikhlasan, kedisplinan dan kepemimpinan adalah salah satunya.

Penulis memilih Gramedia Pustaka Utama sebagai penerbitnya. Awalnya Fuadi mengirimkan naskah novelnya kepada dua penerbit, dan Gramedialah yang memberikan jawaban pertama. Atas rekomendasi seorang teman Fuadi kemudian memutuskan memilihGramedia. Hal ini dikarenakan Gramedia memiliki jaringan pemasaran diseluruh Indonesia. Sesuai dengan misi utamanya untuk berbagi inspirasi dan wawasan kepada lebih banyak orang tentang pendidikan pesantren. Peneliti kemudian mewawancarai salah satu pembaca Negeri 5 Menara. Pembaca yang dipilih adalah yang tidak pernah merasakan pendidikan pesantren, asrama atau pendidikan sejenis lainnya. Hal ini untuk menjaga keakuratan opini yang tidakbercampur dengan konteks sosial di luar Negeri 5 Menara dan agar focus terhadap opini tentang metode pendidikan pesantren yang ada dalam novel tersebut. Pembaca yang dipilih adalah Anis Setyawati, mahasiswa Pascasarjana Pendidikan Bahasa dan Sastra Indonesia yang juga penggemar karya sastra.

Sejak awal membaca novel ini, Anis begitu tertarik dengancerita yang ada didalamnya. Meskipun tak pernah merasakan pendidikan yang ada dalam pesantren, ia tidak mempermasalahkan isi kandungan novel yang banyak bercerita tentang pendidikan pesantren. Anis juga mengenal Negeri 5 Menara secara langsung tidakmelalui rekomendasi teman atau media lainnya. la membaca langsung sinopsis novel tersebut dan merasa tertarik dengan kandungan novelnya. Awal ketertarikannya adalah cerita tentang pendidikan yang ditawarkannovel ini mirip dengan tetralogi Laskar Pelangi yang juga ia gemari.Meskipun banyak bercerita tentang pendidikan pesantren, bagi Anis pendidikan itu adalah sesuatu yang universal, tidak pedulipendidikan agama atau umum. la juga ingin tahu bagaimana orang-orangdi pesantren dididik dan dimotivasi. Sebelum membaca Negeri 5 Menara,Anis tidak begitu banyak mengetahui tentang pendidikan pesantren. la mengetahui tentang pendidikan berasal dari teman-temannya yang juga alumni dari pondok pesantren. Menurutnya alumni pesantren memiliki pengetahuan agama yang kuat. Selain itu, lulusan pesantren juga memiliki kemampuan bahasa asing yang bagus terutama bahasa Inggris dan Arab. 
Setelah membaca Negeri 5 Menara, ada keinginan Anis untuk sekolah di lembaga pendidikan yang menerapkan pola pendidikan seperti yang tertuang dalam novel ini. Tidak harus pesantrennya, tetapi metode yang diterapkannya, seperti pendidikan bahasa yang kuat. Bahkan terbesit keinginannya untuk sekolah di asrama dengan model pendidikan seperti pesantren dalam Negeri 5 Menara.Pesantren di novel ini terinspirasi oleh Pondok Modern Gontor,Setelah membacanovel ini ada keinginan Anis untuk mengunjungi Gontor dan melihatlangsung pola pendidikan seperti yang digambarkan di Negeri 5 Menara.Secara keseluruhan Anis menganggap novel ini sangat inspiratif danmemacu keinginan untuk belajar bahasa asing sedini mungkin dan belajarkeras dengan secara terus menerus dan tak kenal kata menyerah. Dari uraian diatas kita dapat melihat bagaimana tujuan penulis membuat novel ini yaitu untuk mengenalkan pola pendidikan pesantren yang sebelumnya tidak banyak diketahui banyak orang tersampaikan kepada yang membaca novel tersebut. Pola pendidikan tersebut juga memberikan inspirasi kepada pembacanya untuk semangat menuntut ilmu dan belajar.

C. Dimensi Praktis Sosial Budaya (Makrostruktural)

Analisis sosial budaya didasarkan pada asumsi bahwa konteks sosial yang ada di luar media mempengaruhi bagaimana wacana yang muncul dalam media. Sosial budaya ini memang tidakberhubungan langsung dengan produksi teks, tetapi ia menentukan bagaimana teks diproduksi dan dipahami. Ideologi ini diproduksi dan direproduksi di banyak tempat dan banyak bidang kehidupan, media adalah salah satu diantaranya. Sosial budaya menggambarkan bagaimana kekuatan-kekuatan yang ada dalam masyarakat memaknai dan menyebarkan ideologi yang dominan kepada masyarakat.

Menurut Fairclough, hubungan itu bukan langsung, tetapi dimediasi oleh sosial budaya. Mediasi itu meliputi dua hal, yaitu pertama, bagaimana teks tersebut diproduksi dan kedua khalayak juga akan mengonsumsi dan menerima teks tersebut dalam pandangan yang sama sesuai dengan keinginan media. Fairclough membuat tiga level analisis pada sosial budaya: level situasional, instituasional dan sosial.

\section{Tingkat Situasional}

Ide awal Negeri 5 Menara muncul ketika penulis mengenyampendidikan di Pondok Modern Gontor. Namun, hal tersebut tertunda karena kesibukan penulis. Menurut penulis, naskah novel ini dikerjakan pada tahun 2008. Saat itu industri buku juga sedang mengalami kemajuan pesat pasca euforia novel Tetralogi Laskar Pelangi karya Andrea Hirata. Banyak novel sejenis yang bermunculan seperti $5 \mathrm{~cm}$ dan 9 Matahari. Buku-buku tersebut umumnya berisikan motivasi untuk mengejar impian dan mengukir cita-cita dan terinspirasi oleh kisah nyata penulisnya.

Begitu juga dengan novel Negeri 5 Menara. Terinspirasi olehkisah nyata penulisnya, secara umum bercerita tentang mengejar impian dan cita-cita. Namun, yang membuat Negeri 5 Menara berbedadengan novel bergenre sama adalah adanya unsur pendidikanpesantren dalam novel tersebut. Selama ini tidak banyak novel yang mengangkat tema tentang latar sekolah pesantren dengan penggambaran pesantren sebagai sebuah lembaga pendidikan yang berkualitas. Bahkan dengan sekolah di pesantren dapat mewujudkan cita-cita hingga sekolah 
di luar negeri. Tidak banyak pula novel yang bercerita tentang metode pendidikan pesantren secara rinci seperti Negeri 5 Menara.

\section{Tingkat Institusional}

Novel ini dibuat secara mandiri oleh penulisnya. Ada beberapa orang yang turut membantu dan menyumbangkan ide dalam penulisannovel ini. Namun, sifatnya hanya mendukung cerita yang naskah awalnya telah dibuatoleh Fuadi sendiri. Draft awal cerita awalnya dibagikan kepada teman-teman terdekat Fuadi untuk dikoreksi dan diberi masukan. Kemudian naskah tersebut dikirim kepada dua penerbit. Penerbit yang kemudian memberi respons terhadap naskah awal Negeri 5 Menara adalah Gramedia Pustaka Utama.

Ahmad Fuadi yakin bekerja sama dengan penerbit ini atas rekomendasi dari seorang teman yang juga seorang penulis. Hal ini dikarenakan Gramedia memiliki jaringan toko buku di seluruh Indonesia. Hal ini tentu berdampak positifterhadap proses pemasaran novel ini. Dengan kerja sama ini, Ahmad Fuadi sedikit demi sedikit telah sampai pada cita-citanya yaitu membagikan pengalamannya selama di Gontor, mengenalkan kepada sebanyak-banyak khalayak tentang pendidikan pesantren, dan berbagi inspirasi, serta menularkan semangat untuk meraih cita-cita dan impian, meskipun berasal dari latar belakang sekolah agama atau pesantren.

\section{Tingkat Sosial}

Pendidikan pesantren bukanlah pendidikan baru di Indonesia. Pesantren sudah ada bahkan jauh sebelum negara Indonesia merdeka.Pondok Modern Gontor yang menjadi inspirasi dari novel ini sendiri sudah berdiri sejak lebih dari 80 tahun silam.Pondok Modern Gontor bermula dari Pondok Gontor "Lama"yang didirikan Kiai Sulaiman Jamaluddin tahun 1800-an. Pesantrenini surut pada masa cucunya, Kiai Santoso. Gontor baru menemukan format terbaiknya setelah September 1926, bertepatan dengan Kongres Umat Islam Indonesia di Surabaya. Kongres itu dihadiri beberapa tokoh nasional seperti HOS Tjokroaminoto, Kiai MasMansyur, Haji Agus Salim, dan AM Sangaji. Ahmad Sahal, putra kelima Kiai Santoso atau generasi ketiga pendiri Pondok Pesantren Gontor Lama juga hadir.Dalam kongres itu, para ulama kesulitan menemukan dutalndonesia untuk dikirim ke Kongres Umat Islam Sedunia di Mekkah, Arab Saudi. Syaratnya, duta itu harus mahir berbahasa Arab sekaligus Inggris. Akhirnya dipilihlah dua orang, yaitu HOS Tjokroaminoto yang mahir berbahasa Inggris dan Kiai Mas Mansyur yang fasih berbahasa Arab.

Peristiwa itu menyadarkan Ahmad Sahal bahwa menguasai bahasa asing adalah pintu dunia. Apalagi, dia menyaksikan lembaga-lembaga pendidikan Katolik di Indonesia saat itu cukup maju pesat dengan kurikullum lebih progresif. Ahmad Sahal akhirnya menetapkan bahasa Inggris dan Arab sebagai bahasa sehari-hari di Gontor,(Kompas,19/09/10).

Pendidikan di Gontor sendiri meniru model berbagai pendidikandi luar negeri. Gontor antara lain mencontoh Universitas Al Azhar di Mesir, yang terkenal dengan kesungguhan mendidik murid berwawasan Islam mendalam. Acuan lain, Sekolah Shantiniketan di India yang didirikan filsuf dan sastrawan Hindu Rabrindanath Tagore yang mengajarkan kedamaian serta kasih sayang. Semangat serupa diambil dari Pondok Syanggit di Mauritania, Afrika Utara 
yangmengembangkan kedermawanan dan keikhlasan, serta Universitas Muslim Aligarh, India, universitas yang memadukan pendidikan umum dan agama. Menurut catatan buku Profil Modern Gontor (2004), era modernitas Gontor diproklamasikan tahun 1936, ketika pondok ini mendirikan sistem pendidikan baru, yaitu Kulliyatul Mu'allimin al-Islamiyah (KMI/Sekolah Guru Islam) (AP\&RR, Kompas, 19/09/10).

Dari uraian sejarah di atas, dapat dilihat bahwa pesantren telah mengusung nilainilai pendidikan yang berbeda dengan lembaga pendidikan umum saat ini. Sejak awal pesantren didirikan, pesantren telah memiliki ruh pendidikan. Menurut Drs. Husnan Bey Fananie,MA dalam majalah Baitul Muslimin, cucu dari pendiri Pondok Modern Gontor ini mengatakan bahwa berbicara mengenai santri maka akan berbicara tentang pendidikan. Karena santri merupakan pendidikan awal dari umat Islam Indonesia, dan ini merupakan bagian yang tidak bisa dilepaskan. Pesantren memiliki kemiripan dengan Shaolin Temple atau pemondokan yang banyak terdapat di India seperti Rabinrath Tagore. Di lembaga-lembaga tersebut, tidak saja dididik ilmu-ilmu agama, tetapi juga ilmu kewirausahaan dan ilmu bela diri sehingga mereka menjadi generasi yang ditempa oleh lingkungan.

Hampir semua pesantren di Indonesia memiliki kesamaan motto, yaitu berbudi tinggi (akhlakul karimah), berbadan sehat, berpengetahuan luas (broadknowledge) dan berpikir bebas (freedom ofthinking). Tidak ada sedikit pun ajaran-ajaran yang diajarkan dipesantren ini yang mengajarkan anarkisme, kekerasan, apalagi hal-hal yang terkait dengan terorisme. Masih menurut Fananie, Pesantren adalah cikal bakal pembangunan intelektual muslim Indonesia, dan menjadi sumber inspirasi pembangunan karakter bangsa ini, terutama umat Islam. Posisi ini sangat strategis sehingga menjadikan pesantren sebagai ujung tombak pembangunan umat Islam Indonesia, dan pondok pesantren juga memiliki semangat interaksi yang tinggi dengan masyarakat sekitarnya. Pesantren itu lahir dari inisiatif dan kemauan kuat masyarakat, tidak ada pesantren yang lahir dari tangan pemerintah.

Arief Ridwan Haris, seorang praktisi pendidikan mengatakan bahwa pendidikan agama lebih unggul daripada pendidikan umum. Menurut pengamatannya keunggulan dari pendidikan agama adalah adanya pendidikan karakter bagi peserta didik. Pendidikan karakter ini mencakup kedisplinan, kemandirian, keikhlasan, menghargai guru dan kemampuan bertahan (survive). Bahkan tokohtokoh di Indonesia lahir dari latar belakang pendidikan agama seperti pesantren. Hidayat Nur Wahid, Maftuh Basyumi, Din Syamsudin, Nurcholish Majid, Hasyim Muzadi adalah sederet tokoh nasional jebolan pesantren. Pendidikan agama saat ini juga tidak memisahkan diri dengan pendidikan umum dan kemampuan keahlian/soft skill. Menurut Fananie pesantren itu tidak hanya mempelajari ilmuilmu agama, tetapi juga ilmu-ilmu lainnya seperti ilmu kehidupan dan pengembangan karakter.

Dari uraian di atas kita dapat melihat bahwa apa yang menjadi isi cerita Negeri 5 Menara sesungguhnya bukan hal yang baru. Metode pendidikan yang diterapkan di Pondok Madani dalam novel sudah diterapkan jauh sebelum Indonesia merdeka di Pondok Modern Gontor. Namun, hal ini tidak banyak diketahui oleh masyarakat umum. Kalangan yanng familiar dengan sistem pendidikan 
pesantren seperti ini hanya berasal dari alumni pesantren atau orang yang sekolah di pendidikan agama saja. Media massa tidak banyak menyoroti sistem pendidikan pesantren atau pun apa yang ada dibalik tembok pesantren. Pemberitaan tentang pesantren cenderung mengaitkan pesantren dengan aksi terorisme di Indonesia.

Negeri 5 Menara merupakan novel yang telah terjual lebih dari seratus ribu eksamplar dan telah mengalami delapan kali cetak. Novel ini juga telah merambah negeri Malaysia dan diterjemahkan dalam bahasa Melayu. Banyaknya pemberitaan yang mengkaitkan pesantren dengan isu teroris tidak berdampak dengan antusias masyarakat untuk mengetahui apa yang terjadi di balik pesantren. Negeri 5 Menara merupakan media yang memberikan gambaran yang rinci mengenai metode pendidikan.

Pola pendidikan di Pondok Madani (PM) dalam Negeri 5 Menara dan semua aktivitas yang wajib diikuti seluruh santri sangat mendukung perkembangan kognitif, afektif, sekaligus motorik. Kognitif mereka tak hanya diasah saat proses belajar-mengajar dalam kelas, tetapi juga ketika jam wajib belajar malam serta melalui klub-klub ekstrakurikuler. Psikomotorik mereka dilatih melalui kewajiban mengikuti kegiatan pramuka dan klub olahraga. Perhelatan Liga Madani, sepak bola antar-asrama, yang selalu ditunggu menunjukkan betapa olahraga sudah menjadi bagian tak terpisahkan bagi para santri.

Bahkan, sang kiai pun tak canggung berganti pakaian dengan kostum sepak bola dan menyepak si bulat bundar itu ke gawang. Lalu, afektif? Secara otomatis terasah ketika setiap santri harus berinteraksi dengan ribuan teman yang datang dari berbagai daerah berbeda di Tanah Air. Berinteraksi dan bersosialisasi dengan mereka, 24 jam sehari. Jadi, ketika saat ini perguruan tinggi beramairamai menunjukkan dan mempromosikan program soft skills yang diberikan untuk menarik minat mahasiswa, PM sudah memberikannya secara berkesinambungan selama empat hingga enam tahun untuk setiap santri. Kepemimpinan mereka dilatih melalui kegiatan organisasi, mulai dari yang terkecil di lingkup kelas, kamar, klub, hingga organisasi di asrama dan pusat. Kesenian digembleng dan ditunjukkan melalui pergelaran seni akbar untuk kelas lima dan enam. Sebuah proses pembelajaran yang menggabungkan kinerja otak kiri dan kanan, menyelaraskan antara intelligence quotient (IQ), emotional quotient (EQ), dan spiritual quotient (SQ). Tanggung jawab ustaz (guru) berkelanjutan, tak hanya mengajar dikelas, tetapi juga siap ditanyai apa pun di luar jam pelajaran. Bahkan menyediakan waktu khusus menjelang ujian membantu para santri saat belajar. Metode ini bisa menjadi referensi bagi para guru dalam mendidik siswa-siswinya bahwa menjadi pendidik tak otomatis berhenti ketika bel pulang sekolah dipukul dan ruang kelas ditutup(Kompas, 01/11/09).

\section{Kesimpulan}

Pertama, secara tekstual ( mikrostruktural) djabarkan penggunaan bahasa dalam novel Negeri 5 Menara karya Ahmad Fuadi terdapat ideologi-ideologi yang diterapkan di pesantren. Penggunaan kata-kata Islami menunjukkan bahwa di dalam Pesantren diajarkan perilaku-perilaku keislaman. Aspek judgements bermuatan positif banyak 
ditemukan pada novel Negeri 5 Menara. Beberapa diantaranya tergambar pada cuplikan "Rumus man jadda wajadda" terbukti mujarab." Kesungguhanku segera dibalas kontan"." Dalam tempo hanya satu jam saja", "secara ajaib kartuku terisi". Penggunaan frasa-frasa tersebut bermuatan positif. Selain itu juga banyak ditemukan affect positif dan apreciation yang juga bermuatan positif yang menjadikan novel ini layak untuk dijadikan referensi bacaan bagi masyarakat secara umum terutama yang punya kepedulian terhadap dunia pendidikan dan keagamaan. Kedua secara kewacanaan (mesostruktural) Novel Negeri 5 Menara ini merupakan pengalaman pribadi pembaca yang dituliskan kembali ke dalam novel dengan maksud apa yang menjadi pengalamannya selama di pondok Gontor bisa menginspirasi banyak orang. Konsumsi masyarakat terhadap novel Negeri 5 Menara ini diharapkan dapat mengubah pandangan Masyarakat terhadap keberadaan pesantren sebagai sebuah lembaga agama yang tradisional, terbelakang, jorok, dan sebagainya bisa diubah dengan membaca novel ini. Apa yang ditampilkan dalam novel ini adalah gambaran tentang sebuah pesantren modern yang tak hanya belajar agama tetapi belajar ilmu umum dan kehidupan pada umumnya. Ketiga secara sosial budaya (Makrostruktural) Novel Negeri 5 Menara ini dilatarbelakangi oleh kehidupan sosial budaya yang syarat akan nilai-nilai religius yang menjadikan ruh dari novel ini benar-benar bernafaskan keislaman dalam setiap sisi penceritaan. Bagaimana seorang anak harus berbakti pada orangtua, bagaimana seorang santri harus tawadhu pada ustadnya, dan bagaimana menjadi pribadi yang baik. Hampir semua pesantren di Indonesia memiliki kesamaan motto, yaitu berbudi tinggi (akhlakul karimah), berbadan sehat, berpengetahuan luas (broadknowledge) dan berpikir bebas (freedom of thinking).

\section{Daftar Pustaka}

Aminuddin. (2009). Pengantar Apresiasi Karya Sastra. Bandung: Sinar Baru Algesindo.

Arikunto, S. (2013). Prosedur Peneltian: Suatu Pendekatan Praktis. Jakarta: Rineka Cipta.

Ayuningtyas, D.I. \& Hartanto, E.C.S. (2014). Pidato Politik di Indonesia: Sebuah Kajian Wacana Kritis. Prosodi, Vol. 8 No. 1 Januari 2014.

Badara, A. (2012). Analisis Wacana: Teori, Metode, dan Penerapannya pada Wacana Media. Jakarta: Kencana Prenada Media Group.

Budianta, M. (2008). Membaca Sastra. Yogyakarta: Indonesia Tera.

Darma, Y. (2009). Analisis Wacana Kritis. Bandung: Yrama Widya Darma.

Fuadi, A. (2009). Negeri 5 Menara. Jakarta: Gramedia Pustaka Utama.

Sobur, A. (2004). Analisis Teks Media. Bandung: Remaja Rosdakarya Offset.

http://www.grammatics.com/appraisal/appraisalguide/framed/framed.html diakses pada tanggal 11 April 2018

Winarni, Sri. (2012). Analisis Appraisal System Kumpulan Wacana"Sungguh-Sungguh Terjadi" Pada Surat Kabar Kedaulatan Rakyat. S1 Thesis, Universitas Negeri Yogyakarta. 